\title{
Seasonal patterns in oil prices and their implications for investors
}

\author{
Peter Arendas \\ Department of Banking and International Finance, \\ University of Economics in Bratislava \\ Slovakia \\ p.arendas@centrum.sk
}

Daniela Tkacova

Department of Banking and International Finance, University of Economics in Bratislava

Slovakia

dana.tkacova@euba.sk

\section{Jan Bukoven}

Department of Banking and International Finance, University of Economics in Bratislava

Slovakia

jan.bukoven@culture.gov.sk

Abstract. This paper focuses on the investigation of oil price seasonal patterns and their exploitability in the investment process. As oil is one of the most important and most traded commodities, a successful investment strategy exploiting seasonal patterns in oil price behaviour may be useful for many retail as well as institutional investors. The results show that during the 1983-2017 period, the Brent and WTI oil prices tended to record abnormally positive returns during the months of March, April and August and abnormally negative returns - during the months of October and November. The analysis also shows that simple investment strategies based on switching between the oil market and money market investments, that are utilizing the oil price seasonal patterns, can outperform in the long term.

Keywords: oil, Brent, WTI, seasonality, investment strategy

JEL Classification: Q02, G11, G15 


\section{INTRODUCTION}

The oil market is the most liquid part of the commodity markets, while the latterare crucial part of the global economy. Commodities traded at the commodity markets are inevitable inputs of which virtually all of the final products are made. This is why their prices have a huge impact on the whole economy. However, commodities are not only simple inputs, they are also investment assets that are in the middle of attention of numerous retail as well as institutional investors. This is why commodity markets and various factors affecting commodity prices are studied by many economists (Androniceanu, \& Popescu, 2017; Balaz, \& Zabojnik, 2010; Burciu, 2017; Dudzinski, 2010; Back et al., 2013; Smiech et al., 2015; Vychytilova, 2015; Han et al., 2016; Karyotis, \& Alijani, 2016; Bianchi et al., 2016; Huchet \& Fam, 2016; Ntananamis, \& Zhou, 2016; Pirrong, 2017; Ghoddusi, \& Emamzadehfard, 2017; Olah el al., 2017 etc.; Simionescu, 2017; Vovk, I., Vovk, Y., \& Lyashuk, O., 2017).

Oil is the main source of energy nowadays. It is the most traded commodity and its price movements have a strong impact on real economy as well as on financial markets, where various oil-backed financial derivatives, ETF funds and stocks of oil producers, processors and also consumers are traded. The importance of oil for the global economy could be seen especially during the oil crises of the 1970's, when high oil prices led to a global economic slow-down and a significant growth of inflation. Some of the recent studies (Arendas, 2017a) indicate there are some seasonal patterns in the oil price behaviour and that these patterns may be exploited by investors. The abovementioned study also investigated presence of the Halloween effect on the oil market. It showed that the oil market doesn't follow the Halloween effect pattern, however, it also showed that the oil market tends to do much better during the summer-half of the year. The aim of this paper is to investigate the oil price seasonal patterns and to propose an investment strategy that enables their exploitation.

\section{LITERATURE REVIEW}

Oil is one of the most important as well as most traded commodities. The oil price has a strong impact on the macroeconomic indicators such as inflation, GDP growth rate, balances of trade, etc. It has also a direct and indirect impact on profitability and stock prices of many stock companies. This is why the economic literature covering various oil-related problematics is quite extensive.

A big group of authors analysed the relation between oil prices and various macroeconomic indicators. According to Evgenidis (2017), the oil price shocks have a significant impact on the economy, however, there is considerable difference between the impacts of shocks that occur during the periods of uncertainty and the shocks that occur during the calm periods. The negative impacts of positive oil price shocks are much stronger if they occur during the periods of uncertainty when the economy faces some kind of stress. Valadkhani and Smyth (2017) investigated the impacts of the daily oil price fluctuations on the U.S. industrial output. They discovered that the response of the industrial production on the price fluctuations is asymmetric, as the oil price decline has a weak and slow positive impact on the industrial output, while the oil price growth has a sharp negative impact on the industrial output. According to Mohaddes and Pesaran (2017), a fall in oil prices leads to lower inflation pressures and interest rates and to higher real equity prices. They also concluded that it has a positive impact on the output, however, it takes approximately 4 quarters to materialise.

As oil is traded not only as a physical commodity, but the vast majority of trades is realized via financial derivatives, usually futures and option contracts, without any physical delivery, oil became an important part of the global financial markets. Many authors paid their attention to the relations between oil prices and financial markets, especially the foreign exchange and stock markets. Chen, et al. (2016) found out that the oil price shocks can explain 10-20\% of long-term variations of the exchange rates of the USD against 
currencies of 16 OECD countries. Raza, et al. (2016) came to a conclusion that volatile oil prices have a negative impact on stock markets of all emerging market countries.

Gozgor and Kablamaci (2014) found out that growing oil prices and weakening USD have a positive impact on the majority of agricultural commodity prices. A similar study was conducted by Pal and Mitra (2017) who discovered a strong positive interdependence between oil price and world food price index, especially its sub-categories of dairy, cereals, vegetable oil and sugar. This phenomenon was explained by the fact that at higher oil prices, it is more profitable to use some of the agricultural commodities for biofuel production. This conclusion was supported also by Winchester and Ledvina (2017) and Paris (2017).

For the oil investors, scientific papers focused on factors impacting the oil prices may be interesting and valuable. For example Huang, et al. (2017) investigated the main factors driving the oil prices. They came to a conclusion that political factors and oil stocks have only a short-term (approximately up to 10 months) impact on oil prices and the condition of the global economy and the oil production levels have a medium- to long-term (up to 60 months) impact. Noguera-Santaella (2016) analysed the impacts of 32 armed and civil conflicts that occurred since 1859 on oil prices. He came to an interesting finding that the analysed geopolitical events had a positive impacts on oil prices before the year 2000, however, their impact has diminished afterwards. Pierru, et al. (2018) investigated the impacts of OPEC's policies on the oil price volatility and Nikitopoulos, et al. (2017) investigated the impacts of oil inventories and consumption on the oil price volatility.

Over the recent decades, quite a lot of attention has been paid to various calendar anomalies affecting the financial markets, such as the Halloween effect (Bouman and Jacobsen, 2002; Witte, 2010), the Turnof-the-month effect (Ariel, 1987; Liu, 2013), the Holiday effect (Lakonishok and Smidt, 1988; Ariel, 1990); Ramadan effect (Akbalik \& Tunay, 2016) or the Month-of-the-year effect (Choudry, 2001; Giovanis, 2009). However, a surprisingly low attention has been paid to the seasonal patterns that appear on the oil market. Auer (2014) discovered that during the 1987-2013 period, on Mondays, the oil price volatility tended to be significantly higher compared to the other weekdays, while the returns tended to be lower. He also proposed a long-short trading strategy that was able to outperform the buy \& hold strategy. Suenaga and Smith (2011) investigated the oil, gasoline and heating oil seasonality from the demand and storage cycle point of view. A study from Arendas (2017a) that investigated the presence of the Halloween effect in various segments of the financial markets discovered that although the oil market is not affected by the Halloween effect, the Brent, WTI, as well as Fateh oil prices tend to deliver notably better returns during the summer (May October) than during the winter (November - April) half of the year. The summer returns tend to be by 58 percentage points higher on average. The difference is big enough to indicate a potentially exploitable seasonality. The aim of this article is to follow up on the abovementioned findings, to investigate the oil market seasonality and to propose an investment strategy that enables to exploit this seasonality.

\section{METHODOLOGY}

The analysis is performed using Brent and WTI oil futures monthly price series provided by Stooq.com databases. The analysed time period spans from March 1983 to December 2017 which includes 417 months. As shown in Table 1, the basic descriptive statistics of the analysed monthly returns, are very similar for both of the oil types. Therefore, it is possible to expect that also the results will be similar for both of them. 
Descriptive Statistics

\begin{tabular}{|l|c|c|}
\cline { 2 - 3 } \multicolumn{1}{c|}{} & Brent & WTI \\
\hline number of months & 417 & 417 \\
\hline average & $0.63 \%$ & $0.61 \%$ \\
\hline median & $0.80 \%$ & $0.87 \%$ \\
\hline minimum & $-32.92 \%$ & $-33.15 \%$ \\
\hline maximum & $44.63 \%$ & $44.62 \%$ \\
\hline standard deviation & 0.09306 & 0.09531 \\
\hline
\end{tabular}

Figure 1 shows that the first 20 years of the analysed time period were relatively calm and the Brent and WTI oil price moved in the \$10-30 range for a better part of time. The situation has changed quite rapidly after 2003. The demand was steeply growing and the supply was often disrupted by various natural catastrophes and political tensions. As a result, the oil prices started to grow. From $\$ 30$ in early 2003, the oil price grew to more than $\$ 140$ (almost to $\$ 160$ on an intra-day basis) in July 2008. The global financial crisis that followed, pushed the oil prices back to the 2003 levels, however, they returned back to triple digit values as soon as in 2011. At the same time, the Brent oil price grew above the WTI oil price, although it is of a lower quality. In late 2014, the oil prices started to decline steeply, as the oil market started to be notably oversupplied due to a rapid growth of shale oil production in the USA. The bottom was reached in early 2016 and oil prices started to recover once again.

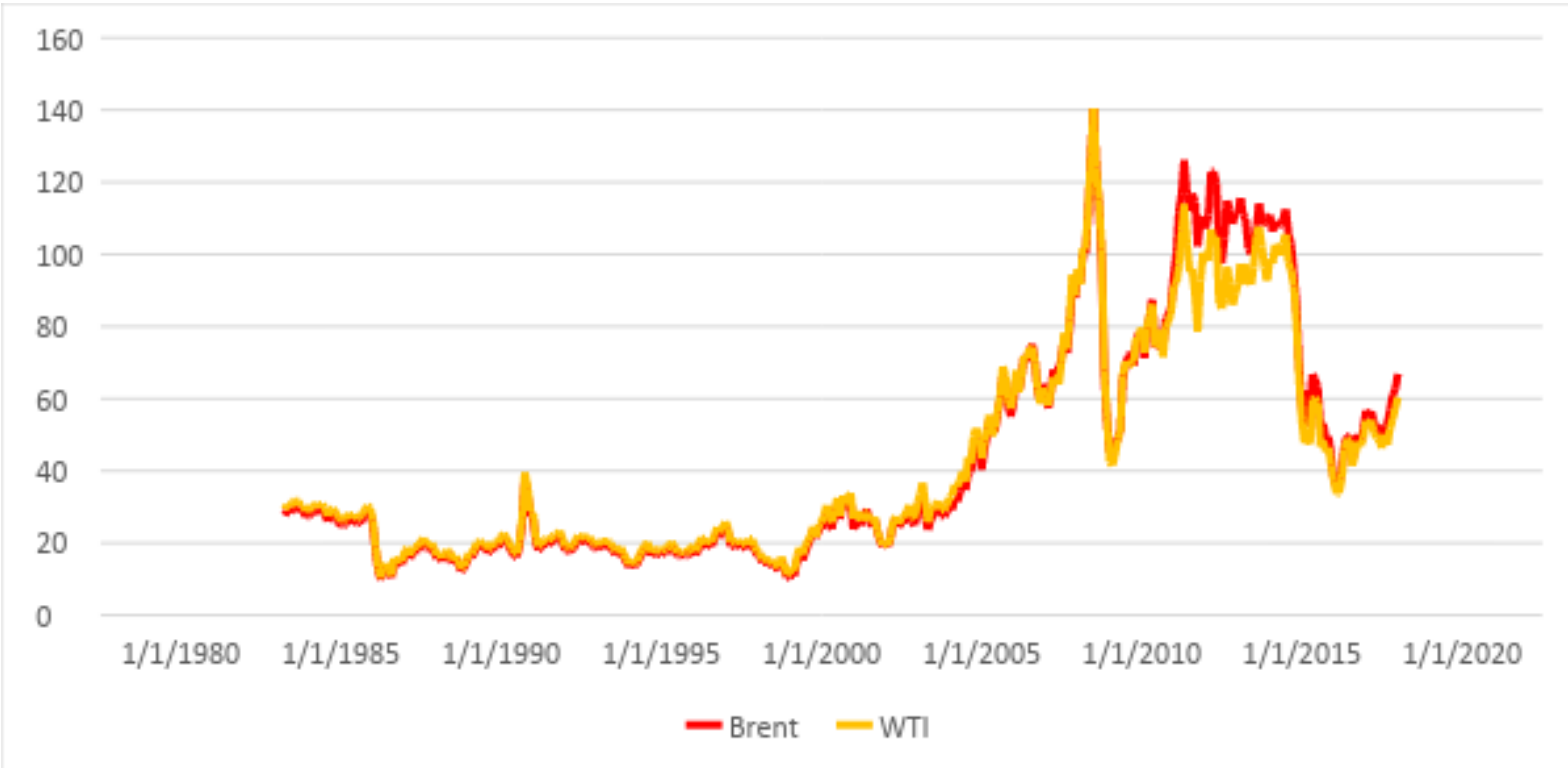

Figure 1. Monthly Oil prices

Source: Own processing

As the previous research of the Halloween effect on commodities markets (Arendas, 2017a; Arendas, 2017b) shows, the oil market isn't affected by the Halloween effect, quite the contrary. The oil market summer period returns tend to be notably higher compared to the winter period returns. A deeper analysis shows that the oil prices tend to raise especially during the months of March, April, August and September, 
while they tend to experience some seasonal weakness during the months of October, November, December and January. Table 2 captures the average monthly returns of Brent and WTI oil, over the 19832017 time period and various sub-periods.

Table 2

Average Monthly Oil Price Returns

\begin{tabular}{|c|c|c|c|c|c|c|c|c|c|c|}
\hline & \multicolumn{10}{|c|}{ Brent } \\
\hline & $\begin{array}{l}1983- \\
2017\end{array}$ & $\begin{array}{l}2009- \\
2017\end{array}$ & $\begin{array}{l}1983- \\
2008\end{array}$ & $\begin{array}{l}1983- \\
1987\end{array}$ & $\begin{array}{l}1988- \\
1992\end{array}$ & $\begin{array}{l}1993- \\
1997\end{array}$ & $\begin{array}{l}1998- \\
2002\end{array}$ & $\begin{array}{l}2002- \\
2007\end{array}$ & $\begin{array}{l}2008- \\
2012\end{array}$ & $\begin{array}{l}2013- \\
2017\end{array}$ \\
\hline JAN & $\begin{array}{c}- \\
0.51 \% \\
\end{array}$ & $-1.50 \%$ & $-0.15 \%$ & $-5.55 \%$ & $-4.11 \%$ & $-0.28 \%$ & $3.46 \%$ & $5.01 \%$ & $0.09 \%$ & $-3.18 \%$ \\
\hline FEB & $0.77 \%$ & $5.92 \%$ & $-1.08 \%$ & $-9.44 \%$ & $-3.24 \%$ & $-1.66 \%$ & $0.88 \%$ & $4.45 \%$ & $8.14 \%$ & $4.23 \%$ \\
\hline MAR & $2.85 \%$ & $0.94 \%$ & $3.54 \%$ & $-0.12 \%$ & $3.73 \%$ & $3.09 \%$ & $9.52 \%$ & $1.40 \%$ & $3.54 \%$ & $-1.80 \%$ \\
\hline APR & $3.65 \%$ & $4.69 \%$ & $3.29 \%$ & $5.18 \%$ & $2.37 \%$ & $3.77 \%$ & $3.49 \%$ & $0.10 \%$ & $4.93 \%$ & $5.73 \%$ \\
\hline MAY & $0.97 \%$ & $-0.84 \%$ & $1.59 \%$ & $2.44 \%$ & $-0.91 \%$ & $-0.98 \%$ & $1.49 \%$ & $3.25 \%$ & $1.33 \%$ & $0.14 \%$ \\
\hline JUN & $0.10 \%$ & $-0.48 \%$ & $0.30 \%$ & $-1.47 \%$ & $-3.50 \%$ & $-1.45 \%$ & $2.00 \%$ & $4.04 \%$ & $1.60 \%$ & $-0.50 \%$ \\
\hline JUL & $0.58 \%$ & $-0.43 \%$ & $0.93 \%$ & $-2.54 \%$ & $4.93 \%$ & $-0.03 \%$ & $-1.55 \%$ & $6.36 \%$ & $1.62 \%$ & $-4.73 \%$ \\
\hline AUG & $3.50 \%$ & $2.10 \%$ & $3.98 \%$ & $8.78 \%$ & $5.76 \%$ & $-0.65 \%$ & $7.56 \%$ & $0.88 \%$ & $\begin{array}{c}- \\
0.77 \% \\
\end{array}$ & $2.91 \%$ \\
\hline SEP & $1.22 \%$ & $-1.67 \%$ & $2.23 \%$ & $-1.16 \%$ & $7.65 \%$ & $4.66 \%$ & $2.93 \%$ & $0.27 \%$ & $\begin{array}{c}- \\
4.20 \%\end{array}$ & $-1.59 \%$ \\
\hline OCT & $\begin{array}{c}- \\
2.09 \% \\
\end{array}$ & $1.20 \%$ & $-3.23 \%$ & $1.26 \%$ & $-1.50 \%$ & $-3.01 \%$ & $-8.35 \%$ & $1.41 \%$ & $\begin{array}{c}- \\
3.98 \% \\
\end{array}$ & $-0.45 \%$ \\
\hline $\mathrm{NOV}$ & $\begin{array}{c}- \\
2.72 \%\end{array}$ & $-0.86 \%$ & $-3.37 \%$ & $-4.27 \%$ & $-3.41 \%$ & $-2.81 \%$ & $-3.12 \%$ & $\begin{array}{c}- \\
0.43 \%\end{array}$ & $\begin{array}{c}- \\
1.28 \%\end{array}$ & $-3.72 \%$ \\
\hline \multirow[t]{3}{*}{ DEC } & $\begin{array}{c}- \\
0.62 \% \\
\end{array}$ & $-0.94 \%$ & $-0.51 \%$ & $-0.86 \%$ & $1.60 \%$ & $-0.19 \%$ & $-0.53 \%$ & $0.70 \%$ & $\begin{array}{c}- \\
1.93 \%\end{array}$ & $-3.13 \%$ \\
\hline & \multicolumn{10}{|c|}{ WTI } \\
\hline & $\begin{array}{l}1983- \\
2017 \\
\end{array}$ & $\begin{array}{l}2009- \\
2017\end{array}$ & $\begin{array}{l}1983- \\
2008\end{array}$ & $\begin{array}{l}1983- \\
1987 \\
\end{array}$ & $\begin{array}{l}1988- \\
1992\end{array}$ & $\begin{array}{l}1993- \\
1997\end{array}$ & $\begin{array}{l}1998- \\
2002\end{array}$ & $\begin{array}{l}2002- \\
2007\end{array}$ & $\begin{array}{l}2008- \\
2012 \\
\end{array}$ & $\begin{array}{l}2013- \\
2017 \\
\end{array}$ \\
\hline JAN & $\begin{array}{c}- \\
0.98 \% \\
\end{array}$ & $-3.11 \%$ & $-0.22 \%$ & $-5.54 \%$ & $-4.12 \%$ & $-0.29 \%$ & $3.29 \%$ & $5.34 \%$ & $\begin{array}{c}- \\
.03 \%\end{array}$ & $-3.44 \%$ \\
\hline FEB & $0.33 \%$ & $3.99 \%$ & $-0.98 \%$ & $-9.45 \%$ & $-3.23 \%$ & $-1.65 \%$ & $0.64 \%$ & $4.69 \%$ & $8.21 \%$ & $1.17 \%$ \\
\hline MAR & $3.22 \%$ & $3.20 \%$ & $3.22 \%$ & $-0.13 \%$ & $3.72 \%$ & $3.09 \%$ & $8.62 \%$ & $0.84 \%$ & $4.22 \%$ & $1.49 \%$ \\
\hline APR & $3.58 \%$ & $5.91 \%$ & $2.77 \%$ & $5.20 \%$ & $2.38 \%$ & $3.76 \%$ & $3.52 \%$ & $\begin{array}{c}- \\
2.83 \% \\
\end{array}$ & $5.56 \%$ & $7.44 \%$ \\
\hline MAY & $0.84 \%$ & $-0.27 \%$ & $1.22 \%$ & $2.45 \%$ & $-0.90 \%$ & $-0.99 \%$ & $-1.17 \%$ & $4.49 \%$ & $0.45 \%$ & $1.53 \%$ \\
\hline JUN & $0.34 \%$ & $-0.23 \%$ & $0.54 \%$ & $-1.47 \%$ & $-3.51 \%$ & $-1.45 \%$ & $3.70 \%$ & $3.50 \%$ & $1.61 \%$ & $0.02 \%$ \\
\hline JUL & $0.37 \%$ & $-1.96 \%$ & $1.17 \%$ & $-2.54 \%$ & $4.94 \%$ & $-0.02 \%$ & $-1.60 \%$ & $7.66 \%$ & $\begin{array}{c}- \\
0.86 \% \\
\end{array}$ & $-5.02 \%$ \\
\hline AUG & $2.77 \%$ & $-0.09 \%$ & $3.76 \%$ & $8.77 \%$ & $5.77 \%$ & $-0.66 \%$ & $6.56 \%$ & $0.48 \%$ & $\begin{array}{c}- \\
2.63 \% \\
\end{array}$ & $1.10 \%$ \\
\hline SEP & $1.82 \%$ & $-0.28 \%$ & $2.55 \%$ & $-1.17 \%$ & $7.65 \%$ & $4.67 \%$ & $3.23 \%$ & $1.28 \%$ & $\begin{array}{c}- \\
3.12 \%\end{array}$ & $0.20 \%$ \\
\hline $\mathrm{OCT}$ & $\begin{array}{c}- \\
2.06 \% \\
\end{array}$ & $1.17 \%$ & $-3.17 \%$ & $1.27 \%$ & $-1.50 \%$ & $-3.03 \%$ & $-7.22 \%$ & $0.61 \%$ & $\begin{array}{c}- \\
2.10 \%\end{array}$ & $-2.43 \%$ \\
\hline $\mathrm{NOV}$ & $\begin{array}{c}- \\
2.70 \%\end{array}$ & $-0.75 \%$ & $-3.38 \%$ & $-4.26 \%$ & $-3.40 \%$ & $-2.79 \%$ & $-2.58 \%$ & $\begin{array}{c}- \\
0.73 \%\end{array}$ & $\begin{array}{c}- \\
0.74 \%\end{array}$ & $-4.40 \%$ \\
\hline DEC & $\begin{array}{c}- \\
0.03 \% \\
\end{array}$ & $0.61 \%$ & $-0.25 \%$ & $-0.86 \%$ & $1.57 \%$ & $-0.20 \%$ & $1.36 \%$ & $1.36 \%$ & $\begin{array}{c}- \\
1.82 \%\end{array}$ & $-1.64 \%$ \\
\hline
\end{tabular}

Source: Own processing 
As the data show, although there are some differences in price behaviour of both of the oil types, the common features are abnormally positive average March, April and August returns (2.85\%, 3.65\% and 3.5\% for Brent, 3.22\%, 3.58\% and 2.77\% for WTI) and abnormally negative average October and November returns $(-2.09 \%$ and $-2.72 \%$ for Brent, $-2.06 \%$ and $-2.7 \%$ for WTI) over the March 1983 - December 2017 time period. It is also possible to see that although the general pattern for some months is slightly disrupted over some sub-periods, for some months the pattern holds over all of them. For example the average April returns of the Brent oil were positive during all of the sub-periods and the November returns were negative during all of the sub-periods. The average March and August Brent returns were positive in all but two subperiods and the average December returns were negative in all but two sub-periods. In the case of WTI, the average March and April returns were positive in all but one sub-period, the average January returns were negative in all but two sub-periods and the average November returns were negative in all of the sub-periods.

Based on the analysis of the seasonal patterns in the oil market behaviour, three alternatives of an investment strategy were proposed. The investment strategy is similar to strategy used by Swagerman and Novakovic (2010), Haggard and Witte (2010) or Andrade et al. (2013) who investigated the ability of a Halloween effect-based investment strategy to outperform the buy \& hold investment strategy. Their strategy was based on investing in the stock market during the November - April period and reinvesting in t-bills during the May - October period. After October ends, the whole cash balance is reinvested back in the stock market and so on, every year over the whole investigated time period. The aim of this strategy is to exploit the tendency of the stock markets to provide better results during the winter half of year. For the purposes of this article, the original strategy was modified in order to reflect the specific oil market seasonal patterns. Based on the abovementioned findings, three alternatives $(A, B, C)$ of an investment strategy were proposed:

- Strategy A assumes investing in oil during the February - September periods and in U.S. 6month t-bills during the October-January periods.

- Strategy B assumes investing in oil during the March - June periods and in U.S. 6-month tbills during the July - February periods.

- Strategy $\mathrm{C}$ assumes investing in oil during the March - April periods and in U.S. 6-month tbills during the May - February periods.

The time periods were set in order to exploit as much of the positive oil price seasonal tendencies as possible, while avoiding as much of the negative oil price seasonal tendencies as possible. Every year was divided into two parts only, as switching between the two investments every two or three months would lead to excessive transaction costs over the long term.

The yields from holding the t-bills are calculated as an aliquot part of the average annualized returns recorded over the particular time period, based on the data provided by the Federal Reserve Economic Data (FRED) databases.

All of the three investment strategies were tested on price data from the March 1983 - December 2017 time period. The results of all of the three strategies were compared with each other as well as with results of the buy \& hold investment strategy that was based on investing in oil in March 1983 and holding the position to the end of December 2017 (it is important to note that the buy \& hold strategy is used for comparison purposes only, as in real market conditions, it could be hardly applied on the futures markets over such a long time period, as the need for rolling the position would destroy the potential returns). To find out whether the efficiency of the investment strategies has changed after the global financial crisis of 2008, also the 2009 - 2017 sub-period was investigated. In relation to the results of the investment strategies application, two hypotheses were set and tested:

- H1: Investment strategies A, B and C are able to outperform the buy \& hold investment strategy over the 1983 - 2017 time period. 
- H2: Investment strategies A, B and C are able to outperform the buy \& hold investment strategy over the $2009-2017$ time period.

In order to determine whether the seasonal patterns in behaviour of oil prices are a persistent phenomenon or whether the average monthly returns for the investigated time period are only a matter of chance, statistical significance tests were performed to determine whether the differences between monthly oil returns recorded during the two parts of the year (February - September vs. October - January, March - June vs. July - February, March - April vs. May - February) were statistically significant during the 1983 - 2017 time period. Parametric two-sample t-test and non-parametric Wilcoxon rank-sum test were used to investigate the statistical significance and to confirm or refute the following hypothesis:

- H3: The differences in monthly oil price returns recorded over the two investigated parts of the year are statistically significant.

\section{EMPIRICAL RESULTS AND DISCUSSION}

The results of all of the analysed investment strategies over the $1983-2017$ time period are presented in Figure 2. As can be seen, strategies A, B and C were able to outperform the buy \& hold strategy significantly, whether talking about the Brent or WTI oil. Over the investigated time period, the Brent and WTI oil prices increased by $141.67 \%$ and 106.28\% respectively. However, all of the three investment strategies based on the discovered oil price seasonality were able to generate more than 12-times higher returns. The best results were recorded by strategy A. The switching between the oil investment during the February - September periods and the money market investments during the October - January periods was able to generate returns of 5,215.66\% in the case of Brent and 4,334.83\% in the case of WTI. Strategies B (investing in oil during the March - June periods and in the U.S. 6-month t-bills over the remainder of each year) and $C$ (investing in oil during the months of March and April and in the U.S. 6-month t-bills over the remainder of each year) provided much lower returns compared to strategy A, but much higher returns compared to the buy \& hold strategy. Both of the strategies were able to generate returns above 1,800\% when applied on Brent and around 2,050\% when applied on WTI.

$5239.64 \%$

$4354.83 \%$

$141.67 \% 106.28 \%$

$\begin{array}{lrrr}\text { Strategy A } & \text { Strategy B } & \text { Strategy C } & \text { Buy \& Hold } \\ & \text { Brent } & \text { WTI }\end{array}$

Figure 2. Results of the Investment Strategies (1983 - 2017)

Source: Own processing 
Figure 3 captures the development of cumulative returns recorded by particular investment strategies when applied on the Brent oil. It is possible to see that strategies A, B and C started to outperform the buy $\&$ hold strategy in the early years of the investigated 1983-2017 time period. The cumulative difference in returns kept on growing for a better part of the following three decades. It is also possible to see that each of the three seasonal strategies had its own time interval when it was able to outperform the other two. Strategy C was the most dominant during the late 80's and 90's, when the oil market was weak, while the tbills provided generous yields above 4\% p.a. In early 2000's, after the oil bull market started, Strategies A and $\mathrm{B}$ started to outperform, as they provided more months of exposure to the growing oil prices.

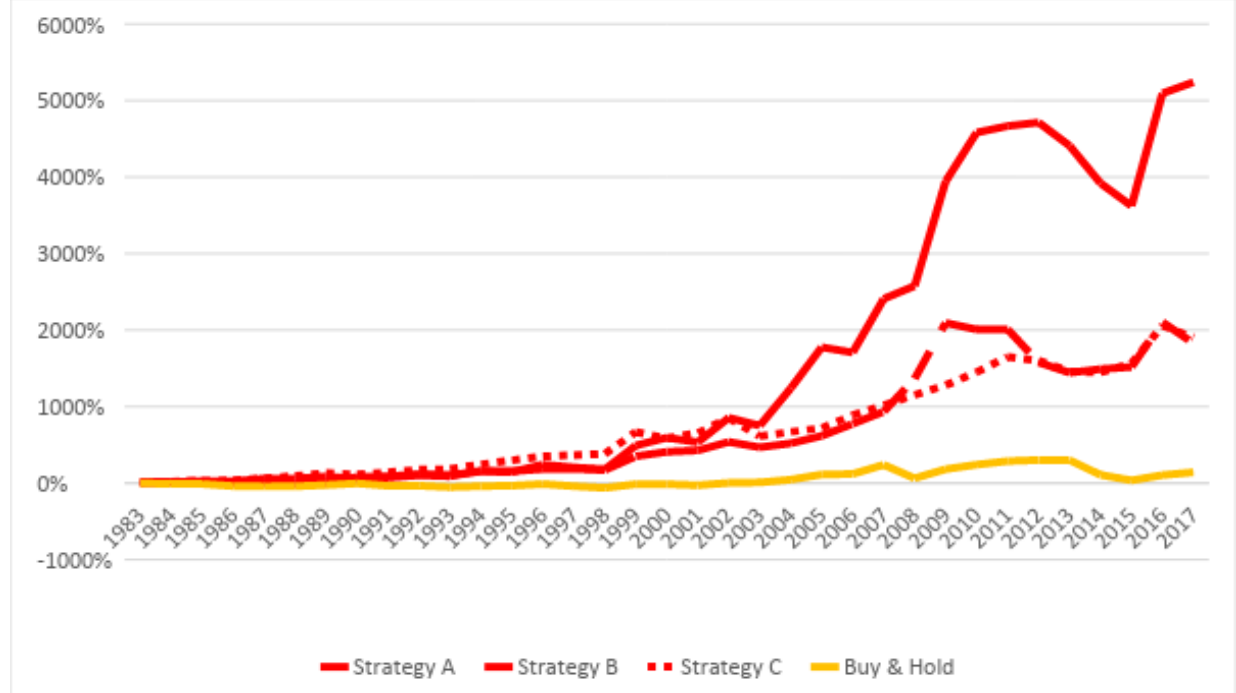

Figure 3. Comparison of investment strategies - Brent (1983 - 2017) (cumulative returns) Source: Own processing

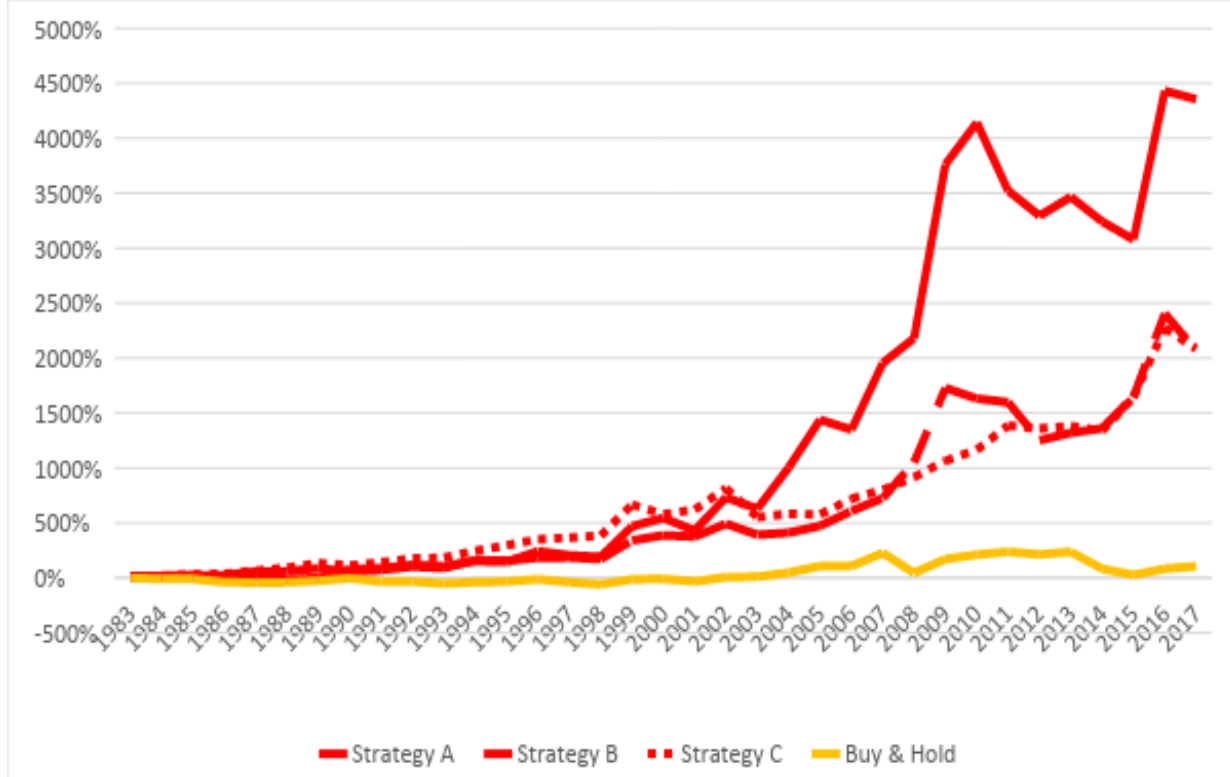

Figure 4. Comparison of investment strategies - WTI (1983 - 2017) (cumulative returns)

Source: Own processing 
Figure 4 is similar to Figure 3, however, it doesn't show the results for Brent oil but the results for WTI oil. The biggest difference between Figures 3 and 4 can be seen in the period following the Global financial crisis of 2008, as the Brent price started to outperform the WTI price (Figure 1). The differences in behaviour of both of the types of oil were reflected also by the fact that the gap between the final cumulative returns recorded by strategy A and strategies B and C was much smaller in the case of WTI oil (less than 2,500 percentage points) than in the case of Brent oil (more than 3,000 percentage points).

As can be seen in Figure 5, the efficiency of the investment strategies has changed quite a bit over the post-crisis period $(2009$ - 2017). The results for this time period were affected especially by two important factors. The first one was a very turbulent oil price development when the oil prices quickly grew from the crisis lows around $\$ 40$ back above the $\$ 100$ level, only to crash back down to the $\$ 30$ 's in early 2016. The second one was the extremely expansive monetary policy of the FED that caused that the money market yields (the U.S. 6-month t-bills included) were close to 0 for a better part of the 2009 - 2017 time period.

The most striking difference when comparing the whole period and the $2009-2017$ sub-period is the significant difference between the efficiency of strategies A, B and C for both of the types of oil. Although for both Brent and WTI strategy A was more efficient than the buy \& hold strategy, for Brent oil, strategy B was less efficient than the buy \& hold strategy and strategy $C$ was only slightly more efficient than the buy \& hold strategy. What is interesting, in the case of WTI oil, strategy B provided only slightly worse returns than strategy A and strategy $C$ was even more successful than strategy A (115.21\% vs. $95.33 \%)$.

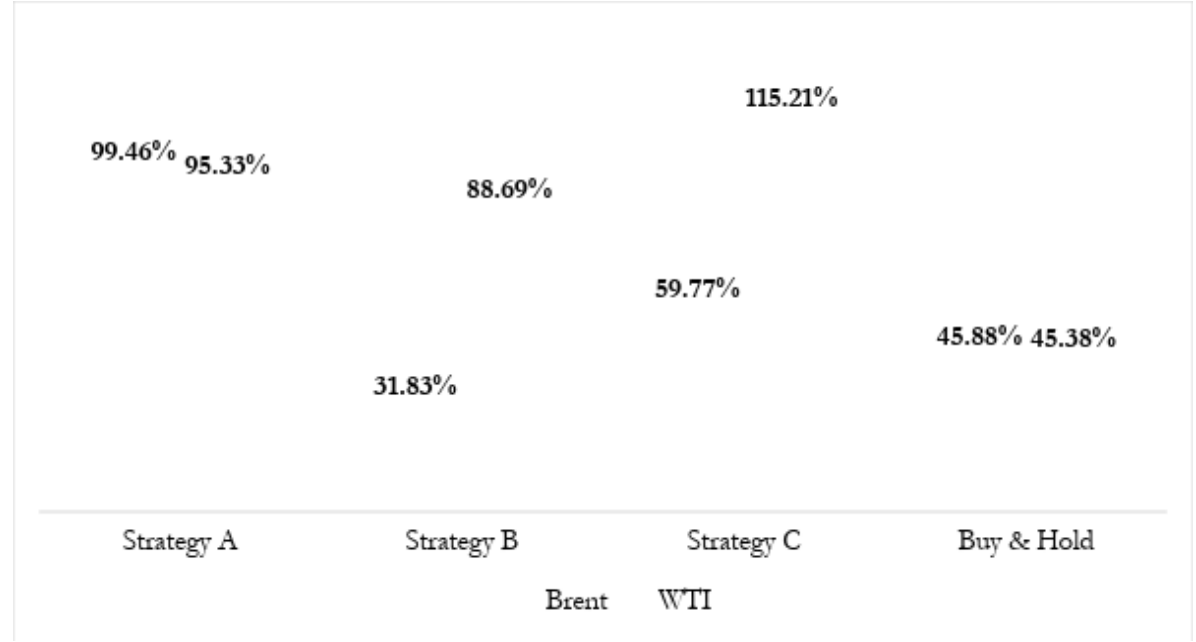

Figure 5. Results of the Investment Strategies (2009 - 2017)

Source: Own processing

The results show that Hypothesis H1 (Investment strategies A, B and C are able to outperform the buy \& hold investment strategy over the 1983 - 2017 time period) can be accepted for both of the types of oil, as all of the three strategies were more successful than the buy \& hold strategy. On the other hand, Hypothesis $\mathrm{H} 2$ (Investment strategies A, B and C are able to outperform the buy \& hold investment strategy over the 2009 - 2017 time period) can be accepted only in the case of WTI oil. In the case of Brent oil, Hypothesis H2 can't be accepted, as strategy B was unable to outperform the buy \& hold strategy.

Table 3 shows results of statistical tests that investigate whether during the $1983-2017$ period, the differences between monthly returns recorded during the time periods used in strategies A, B and C were statistically significant. As the Shapiro-Wilk test shows that all of the analysed data sets are not normally distributed, the non-parametric Wilcoxon rank sum test should be more robust for all of the comparisons. 
The results for the Brent oil show that there are notable differences between average monthly returns recorded during the compared time periods. The biggest difference can be seen when the February September and October - January periods are compared. In this case, the difference is 3.19 percentage points in favour of the February - September period. The statistical significance test shows that in this case, the differences are statistically significant at the 0.01 significance level. When comparing the March - June and July - February time periods, the difference in average monthly returns is 1.87 percentage points in favour of the March - June period. Although the difference is quite notable, it is not statistically significant according to the non-parametric test that should be more robust in this case. Also the comparison of the March - April and May - February periods shows some meaningful differences, specifically 3.14 percentage points in favour of the March - April period. In this case, the differences in monthly returns are statistically significant at the 0.05 significance level.

Table 3

Statistical Significance Tests

\begin{tabular}{|c|c|c|c|c|c|c|}
\hline & \multicolumn{6}{|c|}{ Brent } \\
\hline & FEB-SEP & OCT-JAN & MAR-JUN & JUL-FEB & MAR-APR & MAY-FEB \\
\hline average monthly return & $1.70 \%$ & $-1.49 \%$ & $1.89 \%$ & $0.02 \%$ & $3.26 \%$ & $0.12 \%$ \\
\hline $\begin{array}{l}\text { Two-sample t-test (two- } \\
\text { tailed p-value) }\end{array}$ & \multicolumn{2}{|c|}{0.000893} & \multicolumn{2}{|c|}{0.052969} & \multicolumn{2}{|c|}{0.010379} \\
\hline \multirow[t]{3}{*}{$\begin{array}{l}\text { Wilcoxon rank sum test } \\
\text { (two-sample p-value) }\end{array}$} & \multicolumn{2}{|c|}{0.006557} & \multicolumn{2}{|c|}{0.116514} & \multicolumn{2}{|c|}{0.013593} \\
\hline & \multicolumn{6}{|c|}{ WTI } \\
\hline & FEB-SEP & OCT-JAN & MAR-JUN & JUL-FEB & MAR-APR & MAY-FEB \\
\hline average monthly return & $1.66 \%$ & $-1.45 \%$ & $1.98 \%$ & $-0.06 \%$ & $3.40 \%$ & $0.07 \%$ \\
\hline $\begin{array}{l}\text { Two-sample t-test (two- } \\
\text { tailed p-value) }\end{array}$ & \multicolumn{2}{|c|}{0.001645} & \multicolumn{2}{|c|}{0.038895} & \multicolumn{2}{|c|}{0.007928} \\
\hline $\begin{array}{l}\text { Wilcoxon rank sum test } \\
\text { (two-sample p-value) }\end{array}$ & \multicolumn{2}{|c|}{0.010212} & \multicolumn{2}{|c|}{0.062879} & \multicolumn{2}{|c|}{0.007508} \\
\hline
\end{tabular}

Source: own processing

Relatively similar results provides also the analysis of WTI oil prices. When comparing the February September and October - January periods, the February - September average monthly returns are by 3.11 percentage points higher. The differences in monthly returns are statistically significant at the 0.05 significance level. The March - June period average monthly returns are by 2.04 percentage points higher than the July - February average monthly returns and the differences are statistically significant at the 0.1 significance level. Similar to Brent oil, the biggest difference was recorded when comparing the March April and May - February periods. The difference between the average monthly returns was 3.33 percentage points and it was statistically significant at the 0.01 significance level.

These results show that Hypothesis H3 (The differences in monthly oil price returns recorded over the two investigated parts of the year are statistically significant.) can be accepted for WTI oil, where the differences in monthly returns were statistically significant for all of the three comparisons. In the case of Brent oil, it can't be accepted for strategy B, as the differences between the March - June and July - February monthly returns were not statistically significant.

The results are in line with the findings of an earlier study (Arendas, 2017a) that showed that there are notable differences in oil price behaviour during different parts of the year. The results also show that the 
basic principles of investment strategies focused on exploiting the Halloween effect used by Swagerman and Novakovic (2010), Haggard and Witte (2010) or Andrade et al. (2013) can be modified and successfully used to exploit also other seasonal patterns in asset prices behaviour.

\section{CONCLUSION}

The presented results confirm the previous finding that some seasonal patterns can be found on the oil market. The analysis shows that the oil prices tend to do quite well especially during the March September period, while they tend to underperform from October through January. Moreover, over the 1983-2017 period, the differences in the monthly returns, recorded during the particular parts of the year, were statistically significant. A simple investment strategy of switching between oil and t-bill investments is able to exploit this seasonality and to outperform the buy \& hold strategy notably. This claim is valid also for the post-2008 period, however, during the 2008-2017 period, meaningful differences in price behaviour of Brent and WTI oil could be seen, which affected also the returns generated by the investment strategies. From the long-term point of view, the strategy of investing in oil during the February - September periods and in 6-month U.S. t-bills over the October - January periods, seems to be the most efficient one. During the 1983-2017 period, this investment strategy was able to outperform the buy \& hold strategy significantly, whether applied on Brent or WTI oil.

\section{ACKNOWLEDGEMENT}

This paper is a result of the scientific project VEGA (1/0009/17) "Building of the capital union in Europe and its impacts on individual member countries".

\section{REFERENCES}

Akbalik, M., \& Tunay, K. (2016). An analysis of Ramadan effect by GJR-GARCH model: case of Borsa Istanbul. Oeconomia Copernicana, 7(4), 593-612. doi: https://doi.org/10.12775/OeC.2016.033

Andrade, S.C., Chhaochharia, V., \& Fuerst, M.E. (2013). “Sell in May and Go Away” Just Won’t Go Away. Financial Analysts Journal, 69(4), 94-105. doi: https://doi.org/10.2469/faj.v69.n4.4.

Androniceanu, A., \& Popescu, CR. (2017). An inclusive model for an effective development of the renewable energies public sector. Administrație și Management Public, (28), 81-96.

Arendas, P. (2017a). The Halloween Effect on Financial Markets. Prague, Wolters Kluwer.

Arendas, P. (2017b). The Halloween Effect on the Agricultural Commodities Markets. Agricultural Economics, 63(10), 441-448. doi: https://doi.org/10.17221/45/2016-AGRICECON.

Ariel, R.A. (1987). A Monthly Effect in Stock Returns. Journal of Financial Economics, 18(1), 621-628. doi: https://doi.org/10.1016/0304-405X(87)90066-3.

Ariel, R.A. (1990). High Stock Returns before Holidays: Existence and Evidence on Possible Causes. Journal of Finance, 45(5), 1611-1626. doi: https://doi.org/10.1111/j.1540-6261.1990.tb03731.x.

Auer, B.R. (2014). Daily seasonality in crude oil returns and volatilities. Energy Economics, 43, 82-88. doi: https://doi.org/10.1016/j.eneco.2014.02.005.

Back, J., Prokopczuk, M., \& Rudolf, M. (2013). Seasonality and the valuation of commodity options. Journal of Banking \& Finance, 37(2), 273-290. doi: https://doi.org/10.1016/j.jbankfin.2012.08.025.

Balaz, P., \& Zabojnik, S. (2010). Contemporary Development of the Commodity Markets - Consequences and Challenges for the Revitalization of the World Economy. Ekonomicky Casopis, 58(9), 938-957.

Bianchi, R.J., Drew, M.E., \& Fan, J.H. (2016). Commodities momentum: A behavioral perspective. Journal of Banking \& Finance, 72, 133-150. doi: https://doi.org/10.1016/i.jbankfin.2016.08.002.

Bouman, S., \& Jacobsen, B. (2002). The Halloween indicator, "sell in May and go away": Another puzzle: American Economic Review, 92(5), 1618-1635. doi: 10.1257/000282802762024683. 
Burciu, A. (2017). Technology and labour market in the European Union. Economics, Management and Sustainability, 2(1), 36-42. doi:10.14254/jems.2017.2-1.3.

Chen, H., Liu, L., Wang, Y., \& Zhu, Y. (2016). Oil price shocks and U.S. dollar exchange rates. Energy, 112, 1036-1048. doi: http://dx.doi.org/10.1016/j.energy.2016.07.012.

Choudry, T. (2001). Month of the year effect pre-WWI stock returns: Evidence from a non-linear GARCH model. International Journal of Finance and Economics, 6(1), 1-11. doi: https://doi.org/10.1002/ijfe.142.

Dudzinski, J. (2010). Financial investors in international raw materials and food markets and price movements of those commodities. Economics \& Sociology, 3(1), 25-33.

Evgenidis, A. (2017). Do all oil price shocks have the same impact? Evidence from the Euro Area. Finance Research Letters, (In Press). doi: https://doi.org/10.1016/j.frl.2017.12.013.

Ghoddusi, H., \&Emamzadehfard, S. (2017). Optimal hedging in the US natural gas market: The effect of maturity and cointegration. Energy Economics, 63, 92-105. doi: https://doi.org/10.1016/j.eneco.2017.01.018.

Giovanis, E. (2009). Calendar Effects in Fifty-five Stock Market Indices. Global Journal of Finance and Management, 1(2), $75-98$.

Gozgor, G., \& Kablamaci, B. (2014). The linkage between oil and agricultural commodity prices in the light of the perceived global risk. Agricultural Economics, 60(7), 332-342.

Haggard, K.S., Jones J.S., \& Witte, H.D. (2015). Black cats or black swans? Outliers, seasonality in return distribution properties, and the Halloween effect. Managerial Finance, 41(7), 642-657. doi: https://doi.org/10.1108/MF-072014-0190.

Han, Y., Hu, T., \& Yang, J. (2016). Are there exploitable trends in commodity futures prices? Journal of Banking \& Finance, 70, 214-234. doi: https://doi.org/10.1016/j.jbankfin.2016.04.013.

Huang, S., An, H., Wen, S., \& An, F. (2017). Revisiting driving factors of oil price shocks across time scales. Energy, 139, 617-629. doi: https://doi.org/10.1016/j.energy.2017.07.158.

Huchet, N., \& Fam, P.G. (2016). The role of speculation in international futures markets on commodity prices. Research in International Business and Finance, 37, 49-65. doi: https://doi.org/10.1016/j.ribaf.2015.09.034.

Karyotis, C., \& Alijani, S. (2016). Soft commodities and the global financial crisis: Implications for the economy, resources and institutions. Research in International Business and Finance, 37, 350-359. doi: https://doi.org/10.1016/i.ribaf.2016.01.007.

Lakonishok, J., \& Smidt, S. (1988). Are Seasonal Anomalies Real? A Ninety-year Perspective. Review of Financial Studies, 1(4), 403-425. doi: https://doi.org/10.1093/rfs/1.4.403.

Liu, L. (2013). The Turn-Of-The-Month Effect in the S\&P 500 (2001-2011). Journal of Business and Economics Research, 11(6), 269-276. doi: https://doi.org/10.19030/iber.v11i6.7888.

Mohaddes, K., \& Pesaran, M.H. (2017). Oil prices and the global economy: Is it different this time around? Energy Economics, 65, 315-325. doi: http://dx.doi.org/10.1016/j.eneco.2017.05.011.

Nikitopoulos, C.S., Squires, M., Thorp, S., \& Yeung, D. (2017). Determinants of the crude oil futures curve: Inventory, consumption and volatility. Journal of Banking and Finance, 84, 53-67. doi: 10.1016/j.jbankfin.2017.07.006.

Noguera-Santaella, J. (2016). Geopolitics and the oil price. Economic Modelling, 52, 301-309. doi: http://dx.doi.org/10.1016/j.econmod.2015.08.018.

Ntantamis, C., \& Zhou, J. (2015). Bull and bear markets in commodity prices and commodity stocks: Is there a relation? Resource Policy, 43, 61-81. doi: https://doi.org/10.1016/j.resourpol.2014.10.002.

Olah, J., Lengyel, P., Balogh, P., Harangi-Rakos, M., \& Popp, J. (2017). The role of biofuels in food commodity prices volatility and land use. Journal of Competitiveness, 9(4), 81-93. doi: https://doi.org/10.7441/joc.2017.04.06.

Pal., M., \& Mitra, S.K. (2017). Interdependence between crude oil and world food prices: A detrended cross correlation analysis. Physica A, 492, 1032-1044. doi: https://doi.org/10.1016/j.physa.2017.11.033.

Paris, A. (2017). On the link between oil and agricultural commodity prices: Do biofuels matter? International Economics, In Press. doi: https://doi.org/10.1016/j.inteco.2017.12.003.

Pierru, A., Smith, J.L., \& Zamrik, T. (2018). OPEC’s Impact on Oil Price Volatility: The Role of Spare Capacity. Energy Journal, 39(2), 103-122. doi: 10.5547/01956574.39.2.apie.

Pirrong, C. (2017). The economics of commodity market manipulation: A survey. Journal of Commodity Markets, 5, 1-17. doi: https://doi.org/10.1016/j.jcomm.2017.02.001. 
Raza, N., Shahszad, S.J.H., Riwari, A.K, \& Shahbaz, M. (2016). Asymmetric impact of gold, oil prices and their volatilities on stock prices of emerging markets. Resource Policy, 49, 290-301. doi: http://dx.doi.org/10.1016/j.resourpol.2016.06.011.

Simionescu, M., Lazányi, K., Sopková, G., Dobeš, K., \& Balcerzak, A.P. (2017). Determinants of Economic Growth in V4 Countries and Romania. Journal of Competitiveness, 9(1), 103-116.

Smiech, S., Papiez, M., \& Dabrowski, M.A. (2015). Does the euro area macroeconomy affect global commodity prices? Evidence from a SVAR approach. International Review of Economics \& Finance, 39, 485-503. doi: https://doi.org/10.1016/j.iref.2015.07.012.

Suenaga, H., \& Smith, A. (2011). Volatility Dynamics and Seasonality in Energy Prices: Implications fo Crack-Spread Price Risk. The Energy Journal, 32(3), 72-58. doi: 10.5547/ISSN0195-6574-EJ-Vol32-No3-2.

Swagerman, D., \& Novakovic, I. (2010). Multi-National Evidence on Calendar Patterns in Stock Returns: An Empirical Case Study on Investment Strategy and the Halloween Effect. The International Journal of Business and Finance Research, 4(4), 23-42.

Valadkhani, A., \& Smyth, R. (2017). How do daily changes in oil prices affect US monthly industrial output? Energy Economics, 67, 83-90. doi: 10.1016/j.eneco.2017.08.009.

Vovk, I., Vovk, Y., \& Lyashuk, O. (2017). Improvement of the organizational-economic mechanism of resource-saving at the machine building enterprise. Economics, Management and Sustainability, 2(2), 6-14. doi:10.14254/jems.2017.22.1.

Vychytilova, J. (2015). Linkages among U.S. Treasury Bond Yields, Commodity Futures and Stock Market Implied Volatility: New Nonparametric Evidence. Journal of Competitiveness, 7(3), 143-158. doi: https://doi.org/10.7441/joc.2015.03.10.

Winchester, N., \& Ledvina, K. (2017). The impact of oil prices on bioenergy, emissions and land use. Energy Economics, 65, 219-227. doi: 10.1016/j.eneco.2017.05.008.

Witte, H.D. (2010). Outliers and the Halloween Effect: Comment on Maberly and Pierce. Econ Journal Watch, 7(1), 9198. 